\title{
Extractive Capital, the State and the Resistance in Latin America
}

\author{
Henry Veltmeyer \\ Department of Development Studies, Autonomous University of Zacatecas, Mexico
}

Copyright $\bigcirc 2016$ by authors, all rights reserved. Authors agree that this article remains permanently open access under the terms of the Creative Commons Attribution License 4.0 International License

\begin{abstract}
This paper reviews and discusses the current dynamics of capitalist development in Latin America, with reference to the role of the state, in the form of the post neoliberal regimes formed in the latest 'progressive cycle' of Latin American politics, and the popular resistance to the operations of extractive capital. The context for this discussion is the form taken by extractive capitalism in the region, namely, 'inclusionary state activism', i.e. neo-developmentalism combined with (neo)extractivism and the (re)primarization of exports.
\end{abstract}

Keywords Latin America, Capitalist Development, Extractive Capital, (Neo)Extractivism, Post-neoliberal(ism), Anti-extractive Resistance

\section{Introduction}

Capitalism as a system of commodity production is often viewed as both a powerful engine of economic growth and as a monster that wreaks havoc on society and nature, not out of malice or because of the self-seeking behavior and greed that it engenders, but simply by virtue of its nature as a system. Nothing has propelled this view of capitalism as much as the aftermath and outcomes of forces set in motion in the 1980s with the installation of what was then a 'new world order'. 1 This new world order, dubbed by many as 'neoliberal globalization', not only set new rules for international trade and the free flow of investment capital but it required of prospective entrants-governments seeking to integrate their economies into the global economy - a structural adjustment of their policies in the direction of privatization, deregulation and liberalization [1]. Nowhere was this 'structural adjustment program' implemented as fully as it was in Latin America, where the implementing agencies of this program

1 This 'new world order' was based on the Washington Consensus on the need to promote a system of free market capitalism and to liberate the 'forces of economic freedom' (as George W. Bush had it in his post-9/11 'National Security Strategy') from the regulatory constraints of the welfare-development state. (the World Bank, the IMF) had acquired the requisite leverage to impose the program. The outcome of this Latin American turn towards a free market form of capitalism based on the ideas of the Mont Pelerin Society ${ }^{2}$ include a conservative counterrevolution in development thought and practice, $^{3}$ the financialization of production and an associated propensity towards crisis, and the emergence of powerful forces of popular resistance against the neoliberal policy agenda. Together, these changes constituted an epoch-defining shift in the form taken by capitalism in Latin America, namely, 'inclusionary state activism' (the use by governments of resource rents to bring about a more 'inclusive' form of development, i.e. poverty reduction) combined with the extraction of natural resources and the (re)primarization of exports.

This paper seeks to elucidate some critical dimensions of this process. First, it describes the dynamic pattern in the inflows of capital (foreign direct investments) unleashed by the neoliberal policy agenda. This capital, in the first instance, was to a significant extent directed towards the purchase of the assets of the state enterprises put up for sale by the neoliberal regimes that came to power in the 1990s [4]. In response to changing conditions in the world market that included a demand for primary commodities an increasing proportion of these capital flows were 'resource-seeking', driven by the search for the commodities that would feed this demand.

The second part of the paper outlines the changing role of the state in this process, with particular reference to the post-neoliberal governments that were formed in South America in a tidal wave of regime change. It is there that much of these resource-seeking investments were directed

2 The Mont Pelerin Society was a neoliberal thought collective established in the 1930s but that did not achieve policy influence until the conservative counterrevolution of the early 1980s [2]. Another effective agency for promoting neoliberalism in corporate circles is McKinsey \& Company, a worldwide management consulting firm, whose clientele includes the CEOs of many of the world's largest corporations today $(80 \%$ according to wilkipedia), and an extensive list of governments.

3 On this counterrevolution, see in particular Toye [3]. The major feature of this counterrevolution is turning away from the state as the fundamental agency of economic development (the development state) and towards the market, freed from regulatory constraints. 
and where the governments of the day sought to take advantage of the 'economic opportunities' presented by the new trend towards 'inclusive economic growth' and 'sustainable natural resource development'.

The third part briefly discusses the policy dynamics of the post-neoliberal regimes formed in the first decade of the new millennium as well as the search for a new economic model based on what has been described as the 'new extractivism' ('inclusionary state activism' vis-à-vis the resource rents collected from the capitalist development process of natural resource extraction). Various dimensions of this neoextractivism are discussed before the forces of popular resistance engendered by this new model are brought into a brief analytical focus.

\section{The New Geoeconomics of Capital and the Extractive Industries in Latin America}

The neoliberal reforms that were implemented as the price of admission into the new world order released 'forces of economic freedom' from the regulatory constraints of the developmental state, and in this context they generated a massive inflow of capital in search of profit-making opportunities based on assets, resources and markets. This was in the 1990s, which saw a six-fold increase in the inflows of capital in the form of FDI in the first four years of the decade and then another sharp increase from 1996 to 2001, which tripled, in fewer than ten years, the foreign capital accumulated in the region in the form of foreign-company subsidiaries $[5, \mathrm{p} 71]{ }^{4}$

Another major inflow occurred in the first decade of the new millennium, in conditions of a worldwide primary commodities boom that in the region affected primarily South America. In 2009 Latin America received 26 percent of the capital invested globally in mineral exploration and extraction [6]. According to the Metals Economics Group, a 2010 bonanza in world market prices led to another increase of 40 percent in investments related to mineral exploration, with governments in the region, both neoliberal and post-neoliberal, competing fiercely for this capital. In 2011 South America attracted 25 percent of global expenditures related to mining exploration [7].

4 The 'real FDI boom in Latin America and the Caribbean', according to the Economic Commission for Latin America and the Caribbean (ECLAC) took place in the second half of the 1990s when many State-owned assets were privatized and many sectors, which until then had received little FDI, were opened up and deregulated. It was during this period that the multinationals began to expand their role in the regional economy. Their level of influence held steady in the years immediately after the boom (between 2002 and 2009) and has recently started to trend slightly up again $(5, \mathrm{p} 72)$.
The main targets for FDI in Latin America over the past two decades have been services (particularly banking and finance) and the natural resources sector ${ }^{5}$ - the exploration, extraction and exploitation of fossil and biofuel sources of energy, precious metals and industrial minerals, and agrofood products. ${ }^{6}$ In the earlier era of state-led development, FDI had predominantly served as a means of financing the capitalist development of industry and a process of 'productive transformation' (technological conversion and modernization), reflected in the geoeconomics of global capital and the dynamics of FDI flows at the time. However, the new world order and two generations of neoliberal reforms changed and dramatically improved conditions for capital. For one thing, it opened up in Latin America a market for U.S. technology and investment, and goods manufactured at the center of the system. And it also provided greater opportunities for resource-seeking capital-consolidating the role of Latin America as a source and supplier of natural resources and exporter of primary commodities - a role reflected in the flows of productive investment away from manufacturing and services towards the extractive sector (see Table 1).

The sectoral shift in the distribution of FDI was particularly evident in the wake of what has been described as a 'global financial crisis' - a development that had such minimal repercussions in Latin America that some analysts (e.g. Porzecanski 10]) would ask, 'What crisis?" In the wake of this supposed crisis, the inflow of resource-seeking investments in 2008 reached unprecedented levels, accentuating the trend towards primarization-or, more precisely, reprimarization ${ }^{7}$ - that can be traced back to the new millennium in the context of the growing demand for energy and minerals, and foodstuffs for the expanding middle class in the emerging markets of China and the other BRIC countries as well as the most advanced economies at the center of the system.

5 The natural resources sector consists of two components, each following a separate trend. The first is oil and gas exploration and exploitation, which is mostly conducted through State-owned enterprises in Latin America, although the industry also receives large inflows of FDI. The second is mining, which, owing in part to its more diversified product base, involves far more players

6 The share of the extractive industries in global inward FDI stocks declined throughout the 1990s until the start of the current commodity boom in 2003, after which it recovered to about nine percent in 2005 (8, figure IV.1). The decline of the primary sector's share in global FDI has been due to its slower growth compared with FDI in manufacturing and services. In absolute terms, however, FDI in the primary sector has continued to grow: it increased in nominal terms nearly five times in the $1970 \mathrm{~s}, 3.5$ times in the $1980 \mathrm{~s}$, and four times from 1990 to 2005 (8, annex Table A.I.9). The stock of FDI in extractive industries was estimated at $\$ 755$ billion in 2005 ( 8 , Annex Table A.I.9).

7 On the reprimarization of the economies in the region, in the context of recent changes in the global economy, see (11). As shown in Table 2 the economies of many countries in the region, especially in South America were already geared to the export of primary commodities in 1990, at the outset of the new geoeconomics of capital (an increased inflow of FDI, a growing trend towards investments in natural resources). However, it also shows a deepening and extension of this 'structure' in the new millennium. In 1990, according to ECLAC (5) exports of primary products as a percent of total exports in Latin America decreased from $66.9 \%$ in 1990 to $40.9 \%$ in 2000 , but in tandem with a surge in FDI in the first decade of the new millennium it increased to $61 \%$ in 2011 . 
Table 1. Percentage distribution of FDI by sector in Latin America

\begin{tabular}{cccccccccccc}
\hline & $\mathbf{0 0}$ & $\mathbf{0 1}$ & $\mathbf{0 2}$ & $\mathbf{0 3}$ & $\mathbf{0 4}$ & $\mathbf{0 5}$ & $\mathbf{0 6}$ & $\mathbf{0 7}$ & $\mathbf{0 8}$ & $\mathbf{0 9 - 1 3}$ & $\mathbf{1 4}$ \\
\hline & & & & & & & & & & & \\
Resources & 10 & 12 & 12 & 11 & 12 & 13 & 12 & 15 & 30 & 36 & 41 \\
Manufacturing & 25 & 26 & 38 & 35 & 38 & 37 & 36 & 35 & 22 & 23 & 29 \\
Services & 60 & 61 & 51 & 48 & 46 & 48 & 51 & 49 & 47 & 40 & 30 \\
\hline
\end{tabular}

Source: Arellano [9] for 2000-08; ECLAC [10] for 2009-14

The scope of this reprimarization process, and the increasing reliance of neoliberal and post-neoliberal regimes in South America on the export of primary commodities for foreign exchange and fiscal revenues, is evident in the data presented in Table $2 .{ }^{8}$

Table 2. Trend lines of commodity exports, percent of total exports

\begin{tabular}{|c|c|c|c|c|c|c|}
\hline & 1990 & 2000 & 2004 & 2006 & 2008 & 2011 \\
\hline Argentina & 70.9 & 67.6 & 71.2 & 68.2 & 69.1 & 68.0 \\
\hline Bolivia & 95.3 & 72.3 & 86.7 & 89.8 & 92.8 & 95.5 \\
\hline Brazil & 48.1 & 42.0 & 47.0 & 49.5 & 55.4 & 66.2 \\
\hline Chile & 89.1 & 84.0 & 86.8 & 89.0 & 88.0 & 89.2 \\
\hline Colombia & 74.9 & 65.9 & 62.9 & 64.4 & 68.5 & 82.5 \\
\hline Ecuador & 97.7 & 89.9 & 90.7 & 90.4 & 91.3 & 92.0 \\
\hline Mexico & 56.7 & 16.5 & 20.2 & 24.3 & 27.1 & 29.3 \\
\hline Peru & 81.6 & 83.1 & 83.1 & 88.0 & 86.6 & 89.3 \\
\hline Venezuela & 89.1 & 90.9 & 86.9 & 89.6 & 92.3 & 95.5 \\
\hline LA $^{\mathbf{9}}$ & $\mathbf{6 6 . 9}$ & $\mathbf{4 0 . 9}$ & $\mathbf{4 6 . 2}$ & $\mathbf{5 1 . 3}$ & $\mathbf{5 6 . 7}$ & $\mathbf{6 0 . 9}$ \\
\hline
\end{tabular}

Source: ECLAC [5, 13].

At the turn into the new millennium the service sector still accounted for almost half of FDI inflows, but Table 3 points towards a steady and increasing inflows of FDI, an increasing part of which, according to ECLAC, was 'resource-seeking' and had as its destination point the resource sectors (especially mining) of South America's biggest economies [10]. ${ }^{10}$ In 2006 the inflow of resource-seeking capital grew by 49 percent to reach $\$ 59$ billion, exceeding the total FDI inflows of any year since economic liberalization began in the 1990s [8, Figure II.18]. Income on FDI (i.e. profits on capital invested in the resource sector) in 2006 was particularly high in Brazil and

8 In our analysis of different policy regimes Colombia and Mexico can be clearly categorized as 'neoliberal' in the sense of their commitment to the principles of free market capitalism and the Washington Consensus while Argentina, Bolivia, Ecuador and Venezuela can be viewed as 'post-neoliberal' in terms of their rejection of the Washington consensus and what we have described as 'inclusionary state activism'. Peru and Chile present some ambiguities in regard to this classification, although like Argentina they have recently reaffirmed their commitment towards a neoliberal policy agenda (see, for example, their commitment towards the Pacific Alliance).

9 The Table includes data for what are arguably the most important countries implicated in the problematic of extractive capital. All but Mexico are found in South America; together they account for more than 95\% of foreign investments in natural resource extraction in the region.

10 According to ECLAC (5) Canadian FDI in Latin America and the Caribbean is a recent phenomenon, taking place mainly in the 2000-2008 period. Since 1995, from 42 to 56 percent of the Canadian stock of FDI in developing countries has been concentrated in Latin America (CA\$60 billion in 2008, 42 percent of the total). And most of this 'natural resource seeking' FDI went to the mining sector, for both exploration and production.
Chile-US\$14 billion and US\$20 billion respectively, leading to a surge in the share of retained earnings in total FDI inflows. ${ }^{11}$ In the South American countries for which data is available, income on FDI soared from an average of 10 percent in 2000-03 to 61 percent in 2006 [5]. ${ }^{12}$ Despite the global financial and economic crisis at the time, FDI flows towards Latin America and the Caribbean reached a record high in 2008 (US\$ 128.3 billion), an extraordinary development considering that FDI flows worldwide at the time, according to ECLAC, had shrunk by at least 15 percent [5]. This counter-cyclical trend signaled the continuation of the primary commodities boom and the steady expansion of resource-seeking capital in the region-at least until 2012, when, according to ECLAC [10, p 62] the wave of resource-seeking FDI in response to the surge in commodity prices began to contract. In 2012, however, the inflow of resource-seeking FDI into South America, reached US\$ 45 billion (vs. US\$ 31 billion for both manufacturing and services [10].

Table 3. Net inflows of FDI, by leading country in Latin America (US\$ billions)

\begin{tabular}{cccccccc}
\hline & 2000 & 2002 & 2004 & 2006 & 2008 & 2010 & 2012 \\
Argentina & 10.4 & 2.2 & 4.1 & 5.5 & 9.7 & 7.9 & 12.6 \\
Bolivia & 0.7 & 0.7 & 0.1 & 0.3 & 0.5 & 0.6 & 1.1 \\
Brazil & 32.8 & 16.6 & 18.2 & 18.8 & 45.1 & 48.5 & 65.3 \\
Chile & 4.9 & 2.6 & 7.2 & 7.4 & 16.8 & 15.4 & 30.3 \\
Colombia & 2.4 & 2.1 & 3.0 & 6.7 & 10.6 & 6.8 & 15.8 \\
Mexico & 18.0 & 23.7 & 23.7 & 19.3 & 22.0 & 21.4 & 13.4 \\
Peru & 0.8 & 2.2 & 1.6 & 3.5 & 4.1 & 8.5 & 12.2 \\
Venezuela & 4.7 & 0.8 & 1.5 & -0.6 & 1.7 & 1.9 & 3.2 \\
\hline
\end{tabular}

Source: ECLAC [5, p50].

The rapid expansion in the flow of FDI towards Latin

11 In the context of this investment, the region remains the world's leading source of metals: iron ore (24\%), copper $(21 \%)$, gold $(18 \%)$, nickel $(17 \%)$, zinc $(21 \%)$, bauxite $(27 \%)$ as well as silver $(13)$; $(14, \mathrm{p} 87)$. Oil made up 83.4 percent of Venezuela's total exports from 2000 to 2004, copper represented 45 percent of Chile's exports, nickel $33 \%$ of Cuba's exports, and gold, copper and zinc 33 percent of those of Peru. Together with agricultural production, the extraction of oil, gas and metals remains central to the region's exports. From 2008 to 2009 exports of primary commodities accounted for 38.8 percent of total exports in Latin America (16).

12 ECLAC (5, p71) attributes the extraordinary increase in the profits of the multinationals in the region since 2003 to a combination of two factors: a substantial FDI stock and higher returns on that stock - 'a sharp rise in the profitability of FDI in the region.' $(6, \mathrm{p} 71)$. Data on FDI disaggregated by sector shows that investments in the mining and hydrocarbon sectors of Peru, Chile and Colombia generated profitable returns at an average rate of 25 percent. By contrast, returns on investments in Mexico barely averaged three percent. 
America in the 1990s reflected the increased opportunities for capital accumulation provided by the neoliberal policy regimes in the region. In the new millennium, however, conditions of capital accumulation and the context for capitalist development had radically changed. In this context, which included a major realignment of economic power and relations of trade in the world market (especially the emergence of the BRICs) ${ }^{13}$ and the growth in both the demand for and the prices of primary commodities, the shift of FDI towards Latin America signified a major change in the geoeconomics and geopolitics of global capital. For the first time, flows of FDI into Latin America from 2000 to 2007 exceeded that into the United States, surpassed only by flows into Europe and Asia.

The global financial crisis brought about an even more radical change in the geoeconomics of global capital both in regard to its regional distribution (increased flows to Latin America) and sectoral distribution (concentration in the extractive sector). In 2010, in the throes of a financial and production crisis, the advanced capitalist economies at the center of the system and the epicenter of the crisis (the US and the EC) received less than 97 percent of global investment capital - for the first time since UNCTAD has tracked and kept records of these flows, i.e. since 1970 [17]. In 2005, the 'developing' and 'emerging' economies attracted only 12 percent of global flows of productive capital. But in 2010 FDI flows into Latin America increased by 34.6 percent, well above the growth rate in Asia, which was only 6.7 percent [18].

The flow of productive capital into Latin America over the past decade has been fuelled by two factors: commodity prices, which remained high through most of this period, attracting 'natural-resource-seeking investment,' and the solid economic growth of the South American sub-region, which encouraged market-seeking investment. This flow of FDI was concentrated in four South American countries-Argentina, Brazil, Chile and Colombia - which accounted for 89 percent of the sub-region's total inflows. The extractive industry in these countries, particularly mining, absorbed the greatest share of these inflows. For example, in 2009, Latin America received 26 percent of global investments in mineral exploration [6]. And together with the expansion of oil and gas projects, mineral extraction constitutes the single most important source of export revenues for a majority of countries in the region.

Although the flow of resource-seeking capital is concentrated in four South American countries, Brazil accounted for the bulk of FDI flows. FDI flows to it reached a new high in 2008 of US $\$ 45$ billion, 30 percent above the record level posted the year before [5]. Mexico, the second largest recipient of FDI in the region, was hit hard by the financial crisis and consequently saw FDI inflows fall 20 percent over the same year. Much of this fall can be attributed to the decline of FDI in the services and

13 The BRIC, comprised of Brazil, Russia, India and China, constitutes the largest 'emerging' (now consolidated) market—and thus consumer-led driving force - in the world economy today. manufacturing sectors, and reduced US imports. In contrast, 'natural resource seeking FDI' drove an expansion of capital flows into Argentina, Chile and Colombia, especially in the mining sector. Thus, while efficiency- and market-seeking FDI have more weight in private capital flows into Mexico and the Caribbean, resource-seeking FDI accounts for the bulk and weight of FDI in the region [15, p122-23]. Thus, South America today is the center of gravity for the new geoeconomics and geopolitics of global capital - the new extractivism and the postneoliberal state.

\section{Progressive Extractivism: ${ }^{14}$ A New Model for Latin America?}

The new millennium opened with a boom - a primary commodities boom. This was stimulated by changes in the global economy, specifically, the ascent of China as an economic power and the associated demand by industry and the middle class for raw materials (minerals, fuel and food). ${ }^{15}$ The demand for these commodities was stimulated by security needs of some governments related to energy and food as well as the 'economic opportunities' perceived by the multinational corporations in the extractive sector. This demand led to the growth of what the Food and Agriculture Association of the United Nations [19] and the World Bank [20] describe as 'large-scale foreign investment in the acquisition of land'- 'landgrabbing', in the parlance of critical agrarian studies [21].

The volume of the capital deployed to this end (the extraction of non-renewable natural resources) and the profits made in the process are staggering. Higginbottom [22, p193] estimates that from 1997 to 2010 the multinationals that dominate the world economy extracted a total of US $\$ 477.6$ billion in profit and direct investment income from Latin America, most of it derived from primary commodity exports. As for the financial returns to other foreign investors the Financial Times reported that trades in commodities, in the context of the primary commodities boom and the financialization of capitalist production, ${ }^{16}$ led to the accumulation of large reserves of capital and huge fortunes [25]. As Blas [25] observed: 'The world's top commodities traders have pocketed nearly USD250 billion over the last decade, making the individuals and families that control the largely

14 By 'progressive extractivism' reference is made to what in the literature is described as 'neo-extractivism', namely the channelling of resource rents into social programs to ensure a more inclusionary form of development based on the reduction of poverty.

15 The commodity boom can only be connected to the rising demand for commodities in the growing manufacturing industries in many parts of the world. That is, at least a part of the growing financial transactions, the commodity boom and expanding manufacturing operations of transnational corporations are interrelated (a point made by an anonymous review of this paper).

16 Financialization meant a divorce of development finance and developments in the real economy from the economic transactions made in capital markets. Thus, while financial capital had for many years (in the 1950-70s) played an important role as development finance in the expansion of production in the real economy, it has been estimated that at the turn into the new millennium less than five percent of the capital circulating in the diverse capital markets had any productive role whatsoever $(23,24$, p103-4). 
privately-owned sector big beneficiaries of the rise of China and other emerging countries'-and, one might add, beneficiaries of the turn towards extractivism and export primarization.

A wave of resource-seeking foreign direct investment (FDI) was a major feature of the political economy of global capitalist development at the turn into the first decade of the new millennium. Another was neoliberalism's fall from favor as an economic doctrine and model in several countries in Latin America, where powerful social movements successfully challenged this model. Over the past decade, as a result of social movement activism a number of countries in South America underwent a process of regime change - a tilt towards the left in what has been described as 'progressive extractivism'. ${ }^{17}$ The political victories of these democratically elected 'progressive' regimes opened a new chapter in Latin American history. At the same time the wide embrace of resource-seeking foreign direct investment has generated deep paradoxes for these progressive regimes committed to addressing what UNDESA [27] has described as Latin America's 'inequality predicament' (the most unequal distribution of wealth and income in the world ${ }^{18}$ and what diverse organizations representing the indigenous movement have described as 'the crisis of nature'. ${ }^{19}$

Some leaders and social movements in this context speak of revolution-Venezuela's 'Bolivarian' revolution, Bolivia's 'democratic and cultural revolution', and Ecuador's 'citizens' revolution'-and, together with several governments that have embraced the new developmentalism (the search for a more inclusive form of development), these regimes have indeed taken some steps in the direction of poverty reduction and social inclusion, using the additional fiscal revenues derived from resource rents to this purpose. Yet, like their more conservative neighbors-regimes such as Mexico's and Colombia, committed to both neoliberalism and an alliance with 'imperialism'- the left-leaning progressive regimes in the region find themselves entangled in a maze of renewed dependence on natural resource extraction (the 'new extractivism') and primary commodity exports ('reprimarization'). Further, as argued by Gudynas [26], this new 'progressive' extractivism is much like the old 'classical' extractivism in its destruction of both the

17 From the post-neoliberal perspective of the center-left regimes formed in South America over the last decade, a strategy of natural resource extraction is viewed as a means of bringing about a process of inclusive development-using resource rents and taxes on corporate profits as a means of reducing poverty and securing a more equitable distribution of the social product-'progressive extractivism', in the conception of Eduardo Gudynas (26), a senior researcher at the Uruguay-based Latin American Centre of Social Ecology (CLAES).

18 On this well-documented inequality predicament see, inter alia Veltmeyer \& Tetreault (28) and the UNDP (29).

19 There is a growing literature on this 'crisis of nature', which, in the current conjuncture of capitalist development in the region is attributed to the destructive operations of extractive capital. Different studies into the magnitude and diverse dimensions of this crisis, and the assault on nature or 'mother earth' (Pachamama) has led to a substantive literature on the search for an alternative form of development and conceptions of 'living well (vivir bien) in social solidarity and harmony with nature $(25,29)$. environment and livelihoods, and its erosion of the territorial rights and sovereignty of indigenous communities most directly affected by the operations of extractive capital, which continues to generate relations of intense social conflict.

Despite the use by the 'progressive' center-left governments of resource rents as a mechanism of social inclusion and direct cash transfers to the poor, it is not at all clear whether these governments are able or disposed to pursue revolutionary measures in their efforts to bring about more inclusive and sustainable forms of democratic development while continuing to toe the line of extractive capital and its global assault on nature and livelihoods. The problem here is twofold. One is a continuing reliance of these left-leaning post-neoliberal regimes (indeed, all but Venezuela) on neoliberalism ('structural reforms') at the level of macroeconomic public policy. The other relates to the so-called 'new extractivism' based on 'inclusionary state activism' and continued reliance on FDI — on striking a deal with global capital in regard to sharing the resource rents derived from the extraction process.

The problem here relates to the inherent contradictions of extractive capitalism and the machinations of the imperial state in support of extractive capital. These contradictions are reflected in a process of uneven economic and social development - economic concentration tending towards the extremes of wealth and poverty - and what some economists call 'the resource curse' (the fact that so many resource-rich countries are developmentally poor, while many resource-poor countries have achieved a high level of economic and social development). ${ }^{20}$

One expression of this resource curse is what economists term the 'Dutch disease', reflected in the slowdown currently experienced by Brazil in its engine of economic growth - down from an average of over six percent a year from 2003 to 2010 to only 0.9 percent in 2012, a development that can be accounted for by the collapse of industrial exports [33]. Another is the boom-bust cycle characteristic of extractivism and natural resource development. The slowdown of the commodity super-cycle in the same year [34] suggests that extractive capitalism has not yet outgrown this propensity. ${ }^{21}$ A third manifestation of the resource curse is that sites of natural resource extraction cannot be established by design so as to take locational advantage of existing infrastructure, markets and labor supply. Development projects based on natural resource extraction are necessarily localized in enclaves with linkages to the global market but with very few to other sectors of the local and national economy, with the inevitable result of relatively few multiplier effects regarding a broader development process.

20 On this resource curse see Acosta (31) and Auty (32).

21 Global commodity prices dropped by 6 percent in 2012, a marked change from the dizzying growth during the 'commodities supercycle' of 2002-12, when prices surged an average of 9.5 percent a year, or 150 percent over the 10-year period (34). On the other hand, while commodity prices declined overall in 2012, some commodity categories - energy, food, and precious metals - continued their decade-long trend of price increases. 
The 'resource curse' can also be understood and explained in terms of a series of fundamental contradictions intrinsic to capitalism but that assume more extreme proportions under conditions of extractive capitalism, which is based on the exploitation of natural resource wealth, rather than the classic form of capitalism, which is based on the exploitation of labor. This relates to what the French economist Piketty [35] describes as the 'central contradiction' of capitalism, that is, its tendency to produce ever-greater levels of inequality. ${ }^{22}$

Whether or not, as argued by Piketty [35], uneven development and expanding social inequalities are the central contradictions of capitalism, there is no question that extractive capitalism is more inequality generating than the capitalism of the post-Second World war years. The latter was based on the exploitation of the 'unlimited supplies of surplus labor' released in the process of capitalist development of agriculture while the former is technology-intensive and uses relatively little labor in the production process. As a result, labor receives a reduced and disproportionately small share of the social product, particularly in the mining sector.

Even in Bolivia, where the government 'nationalized' the country's reserves of non-renewable fossil fuels and sub-soil mineral resources, it is estimated that labour receives less than 10 percent of the world market value of exported minerals six percent in the case of Argentina and Chile [37, p2] and as little as 1.2 percent in the case of Mexico. Evidently workers in the sector have not benefited from the extraction of minerals and primary commodity exports. James Cypher [38] reports that after four years of booming exports (from 2002 to 2006) the index of the value of real wages in the extractive sector had grown by less than 0.5 percent. This is in contrast with the well-established pattern of cumulative wage increases in the era of post-war state-led development based on 'labor-seeking' FDI, human resource development, and industrialization. In this context, the share of labor (wages and salaries) in the social product (i.e. in the income derived from the production process) settled at a much higher rate - as much as 60 percent - with undeniably positive (although contradictory) development outcomes and implications.

Another contradiction of capitalist development relates to the historical process of transforming traditional forms of agrarian society based on diverse precapitalist relations of production into a modern industrial capitalist system. As some Marxists in the political ecology tradition (e.g. Foster [39]) understand it, the contradiction-between nature and society, or between the logic of capital accumulation and the ecological foundations of society and the economy-is manifest in the ecological unsustainability of industrial

22 Marxists generally attribute this feature of capitalist development to a fundamental imbalance of power between capital and labor, but neo-Marxist theorists of 'dependency' see it as the result of a secondary contradiction between countries on the south and north of a global divide in wealth and incomes, resulting in 'development' in the North and 'underdevelopment' in the South. For a review of the literature and debates surrounding this dependency theory of underdevelopment see, inter alia, Kay (36) capitalism. However, the destructive operations of extractive capital in the new millennium, and the emergence of an evidently new phase in the development process (extractive capitalism), have brought into sharp relief the contours and dynamics of this fundamental contradiction. It could even be argued that in the contemporary context this contradiction between economic development and the biophysical world trumps both the so-called first contradiction (and relation of conflict), that between labor and capital, and the secondary 'north-south' contradiction [40].

Of course, the three contradictions or conflicts (between labor and capital; between nature and economic development; and between the North and South) are interrelated. For example, expanding global production networks of transnational corporations intensify the conflict between labor and capital in the countries such as China and Mexico that host transnational manufacturing investments; and to feed the insatiable appetite for profit it simultaneously leads to a plundering by th multinationals in the extractive sector of the natural resource wealth of resource-rich developing countries.

Perhaps the most serious 'contradiction' of natural resource development is that a large part of the benefits of economic activity are externalized, i.e. appropriated by groups outside the country and region, while virtually all of the costs - economic, social and environmental-are internalized and disproportionately borne by the indigenous and farming communities contiguous to the open pit mines and other sites of extraction. These costs have given rise to powerful forces of resistance-socioenvironmental movements concerned with preventing further enclosures of the global commons (land, labor, natural resources) and with the negative impacts of extractivism on their livelihoods.

\section{Resistance and Class Struggle on the Frontier of Extractive Capitalism}

Socioenvironmental conflicts have been part of South America for a long time. They generally involve communities struggling against the unequal distribution of costs and benefits of natural resource extraction and the negative impact this extraction has on their livelihoods.

There is a burgeoning literature that analyzes the emergence of socio-environmental conflicts related to the extractive sector. This literature can be placed into four categories. First, there are those studies that explore the sociopolitical and cultural implications of such conflicts for development policies and processes [41, 42, 43, 44].

A second set of studies stress the implications of these conflicts on state-building processes as part of shifting interrelations between social movements, corporations and states [45].

A third set of studies explores the negative socioenvironmental impacts of extractivism and the political 
responses of local communities directly affected by them, which is to demand respect for their territorial and human rights and the accountability of powerful state and corporate interests for undermining their sources of livelihood [46, 47, 48]. As Martinez-Alier [46] sees it, conflicts emerge when there are asymmetric expectations and understandings concerning the economic, ecological, social, and cultural value of different resource-sensitive projects.

A fourth small group of studies have begun to explore the regional and international dimensions of extractivism and related socioenvironmental conflicts [49, 50].

A fifth approach focuses on how these conflicts can be managed [51]. From this conflict resolution perspective, the problems associated with the political economy of natural resource extraction are not systemic or endemic but can be 'managed', and the negative impacts or social and environmental costs mitigated. Resource conflict management, it is argued, is a matter of 'corporate social responsibility' and 'good governance', which includes engagement of the communities, even 'civil society', in the process of securing a 'social license' to operate (explore and extract) in addition to a government-issued concession to explore for resources and a license to operate.

In addition and in contrast to these studies, a number of scholars have begun to explore the social class dynamics of these socio-environmental movements that have sprung up on the latest frontier of capitalist development (e.g. Veltmeyer \& Petras [52]). From this class analysis perspective, extractivism represents the emergence of a new form of rentier capitalism based on the pillage of natural resources rather than the more customary exploitation of labor. It can also be seen as a new form of imperialism, which, according to Girvan [53], in the historical context of the Americas has always involved pillage.

From this perspective the socioenvironmental conflicts and resource wars that have surrounded the contemporary operations of extractive capital are viewed as a new form of 'primitive accumulation' as Marx had it (to separate the direct producers from their means of production, forcing their expulsion from the land and leading to their proletarianization). Essentially, it is argued that the operations of extractive capital represent a new form of enclosing the commons-denying the indigenous and farming communities close to the mines and extractive operations of capital access to the global commons of land, water and resources, and denying any respect for the territorial rights claimed by the indigenous communities.

The mechanism of 'enclosure' in this analysis is the concession granted by the state to the corporations to explore for and extract the sub-soil resources (oil and gas, minerals and metals) from land occupied or owned by these communities or their members. Therefore, the form taken by the resistance on the new frontier of extractive capital includes rejection of the economic model used by the governments to make public policy in the area of economic development; the demand that their territorial and human rights be respected; and, above all, protests against the negative impact of extractivism on both their livelihoods and the environment on which they depend.

The destruction of the livelihoods of the communities contiguous to and most directly affected by the operations of extractive capital stems not only from their negative socioenvironmental impacts, but from the contradictory practices and policies associated with resource-driven 'economic development' discussed above. These practices reflect what has been defined as the logic of 'accumulation by dispossession' [54]. This refers to a mode of wealth generation at the social cost of depriving people of their territorial and human rights and causing ecological destruction. Accumulation by dispossession has been characteristic of diverse and prevailing forms of capitalism where accumulation depends on expanding the boundaries of a global market via the privatization and commodification of nature, i.e. land, water, and natural resources such as sub-soil minerals, fauna and the forest. Some suggest that indigenous peoples are particularly vulnerable in this regard since they are directly dependent on nature, the rich biodiversity of rain forests, rivers and land, not only for their livelihood and material subsistence but for their social and cultural reproduction, which is to say, their very existence.

Large-scale mining, particularly in the form of open-pit mining, with the use of cyanide and mercury in the mineral extraction process is responsible for the pollution of the region's precious water reserves. This could potentially lead to the decimation of fish in rivers, health problems for people exposed to contaminated water, loss of fertile land, and shortages of clean water for human and animal consumption. Needless to say, fishing and the husbandry activities of communities located near mining sites are put at risk or are compromised.

As already mentioned the communities of peasant farmers and indigenous peoples are particularly vulnerable [41]. In the region of the Southern Andes - and the border between Chile and Argentina-large-scale mining activities have been responsible for the pollution of mountain glaciers and downstream water, such as in the case of Barrick Gold's Pascua Lama project. Mining is a particularly environment-sensitive industry that has led to conflict in connection to its negative social and ecological consequences. Throughout Latin America out of a total of ongoing 184 resource conflicts 154 of them are mining-related (Table 4). These conflicts have affected 222 communities (179 of them in South America) and involve 247 companies [50, Table 7.1. N.6]. 
Table 4. Socio-environmental conflicts related to mining in Latin America, 2006-2010

\begin{tabular}{ccccc}
\hline $\begin{array}{c}\text { Countries } \\
\text { (selected) }\end{array}$ & Conflicts & Projects & Companies & Communities \\
\hline Argentina & 24 & 30 & 43 & 37 \\
Bolivia & 5 & 6 & 7 & 21 \\
Brazil & 21 & 21 & 37 & 34 \\
Chile & 25 & 28 & 42 & 34 \\
Colombia & 16 & 32 & 21 & 20 \\
Ecuador & 4 & 5 & 4 & 5 \\
Guatemala & 4 & 4 & 7 & 4 \\
Mexico & 13 & 13 & 17 & 15 \\
Peru & 26 & 26 & 42 & 28 \\
& & & &
\end{tabular}

Source: OCMAL [55].

\section{Class Struggle Dynamics of the Resistance}

A class analysis of these socioenvironmental conflicts and associated struggles and social movements is concerned with three sets of issues, each a matter of debate. The first has to do with the social base of these social movements, establishing the social relation of community members to the system of economic production. The second concerns the matter of understanding the relationship of the communities affected by the operations of extractive capital with both the state and with the companies involved, as well as the relationship of capital to the state. A third issue, which is not explored here, concerns the political dynamics of the associated class struggle.

On the first issue, the prevailing view is to see community members as a proletariat, the latest victims of the capitalist development process in which the direct producers are separated from their means of production as a mechanism of capital accumulation - 'accumulation by dispossession', as Harvey [54] has it. In the classical context analyzed by Marx the mechanism of accumulation - the generation of a proletariat, or a class for hire, and with it a reserve army of surplus labor-involved the enclosure of the commons needed by the communities of small-scale direct producers, or peasant farmers, to subsist. In the contemporary context analysts have established two mechanisms of dispossession: one is large-scale foreign investment in the acquisition of land, or 'landgrabbing'; the other is enclosure of the commons by means of a public policy of privatization and commodification, converting natural resources into means of production and productive resources or assets.

Extractivism in the current context is taking diverse forms, including 'landgrabbing ${ }^{23}$ and enclosures of the commons:

23 Landgrabbing makes reference to what the Food and Agriculture Organization of the United Nations (19), terms 'large-scale investments in the acquisition of land'. This phenomenon has expanded dramatically both in Latin America and elsewhere in the context of what we might term 'agro-extractivism'. But our focus on extractivism in the mining sector large-scale foreign investments in the acquisition of land with the aim of securing access to natural resources for extraction and sale on the world market. Although it has not generated significant forces of resistance or any social movements, it has resulted in a relation and condition of conflict with the local communities who are pressured to abandon the land either by the local agents of the foreign or local investors, or by legislative or administrative fiat.

A second dimension of the class struggle on the expanding frontier of capitalism is the relationship of the communities that are negatively impacted by the mining of minerals and metals, and by the commodification and extraction of water and other resources, to the companies in the extractive industry and the state. The relation of these communities to the companies is one of economic exploitation and political conflict. However, the role of the state in this struggle is very much at issue. By a number of accounts (see, for example, the case studies in Veltmeyer \& Petras [52]), because of a coincidence of economic interest (resource rents and additional fiscal resources for the government, super-profit for the companies) the state tends to side with the companies in their relation of conflict with the communities negatively affected by the operations of extractive capital.

A good example of this is Peru under President Humala who came to power in June 2011 with a promise to support local communities against the mining companies (on a platform of 'water before gold'). However, when open and violent protests erupted between the Canadian mining company Minera Afrodita and the Awajun indigenous communities in town of Bagua, during his term, the Armed Forces turned against the protesters, resulting in 33 deaths, 200 wounded and 83 detentions. This event on June 29, 2013, was the last episode of a long process of protests led by the Awajun to oppose the concessions of exploration and exploitation rights to Afrodita in an area located in the Cordillera del Condor region where there has been a long-standing controversy between the government, indigenous communities, and the company [56].

Prior to the decade of the 1990s, the resistance and the popular movements in Latin America were primarily concerned with issues of social class relating to the struggle over land in the countryside and wages and working conditions in the urban centers. In the 1990s, however, the popular movements, with the agency of class-based and community-based social movements, mobilized against the policies of the neoliberal state (and the governing regimes). By the end of the decade, a number of these movements, led by proletarianized peasant farmers, rural landless workers and indigenous communities (for example in Chiapas, Brazil, Ecuador and Bolivia) achieved major gains in their struggle, placing the existing neoliberal regimes on the defensive and provoking a legitimation crisis for the neoliberal state. At the turn of the twenty-first century, for all intents and purposes, neoliberalism was in decline if not dead, no longer able to serve its legitimating function in regard to the idea of

precludes further discussion of the issue. 
globalization and the new world order.

The key agents involved in this 'politics of resistance' against the imperial incursions of capital in the exploitation of natural resources - at least in the Latin American context - were and remain the predominantly indigenous communities that populate the areas ceded by the different governments (be they neoliberal or post-neoliberal in form) to the foreign mining companies for the exploration and exploitation of natural resources in their territorial lands. However, they also include a variety of civil society groups and NGOs that have been drawn into the conflict between global capital and local communities. And the forces of resistance to resource imperialism include new social movements formed to protest against the damage caused by resource extraction to the environment, as well as against its effects on the health and livelihoods of the local population and the miners themselves, who face life-threatening working conditions and health concerns. In other words, many of these movements are rooted in those negatively affected by the impacts of resource extraction and mining operations (for example, Red Mexicana de Afectados por la Minería and the Confederación Nacional de Comunidades del Perú Afectadas por la Minería or CONACAMI).

The social actors who engage these forces of resistance use tactics such as marches and demonstrations, road and access blockades, and other forms of direct collective action to impede mining operations. According to a forum of people, communities and groups affected by the operations of mining capital, the exploitation of the region's mineral resources in 2009 had reached levels never before experienced [57]. Of particular concern was the Amazon region, where abundant deposits of gold, bauxite, precious stones, manganese, uranium and other materials are coveted by the companies operating in the mining sector.

Another concern was the perceived connection between the multinational corporations in the sector and a host of foundations and NGOs with an alleged humanitarian or religious concern for the environment and the livelihoods of indigenous peoples and communities. In this connection, Eddy Gómez Abreu, president of the Parlamento Amazónico Internacional, declared that they had incontrovertible evidence of these multinationals and foundations, under the cover of supposed ecological, religious or humanitarian concerns, collaborat[ing] in the effort to extract ... strategic minerals', as well as espionage and illegal medical experiments on the indigenous population [6]. In effect, he alleged that the mining companies regularly used foundations and other NGOs as one of their tactics to secure the consent of the local population to their projects and operations, and to manipulate them. If this is true, these foundations and NGOs continue the long, sordid history of European missionaries in the Americas of expropriating the lands of the indigenous, but in an updated form.

\section{Conclusions}

The growing protest movement against mining capital and extractivism has engaged the forces of resistance not just against neoliberalism and globalization, but against the operative capitalist system. Thus, the so-called politics of natural resource extraction are not merely a matter of better resource management, a post-neoliberal regulatory regime, a more socially inclusive development strategy or a new form of governance-securing the participation of local communities and stakeholders in decisions and policies in which they have a vital interest. But given the interests that the state represents, and the coincidence of these interests with those of the 'transnational capitalist class' (to use the phrase of some globalization sociologists), the officials and managers of the post-neoliberal state generally side with capital against labor and have not reacted well to the civil society organizations that criticize or resist their mineral policies or extractive projects. The anti-extractivist protests in the region have received international activist (and academic) recognition as part of a global environmental justice movement, but the agents and progressive officials of the post-neoliberal states simply ignore them - and proceed with their geopolitical project: to advance the exploitation of the country's natural resources by global capital in the public interest. Thus the politics of natural resource extraction resolves into a matter of class struggle - of combatting the workings of capitalism and imperialism in the economic interests of the dominant class, and mobilizing the forces of resistance, found in the indigenous communities of semi-proletarianized peasant farmers, against these interests.

\section{REFERENCES}

[1] Petras, J, Veltmeyer H. Unmasking Globalization: The New Face of Imperialism. Halifax: Fernwood Books; 2001.

[2] Mirowski, P, Plehwe, D, editors. The Road from Mont Pelerin: The Making of the Neoliberal Thought Collective. Cambridge: Harvard University Press; 2009.

[3] Toye, J. Dilemmas of Development: Reflections on the Counter-Revolution in Development Theory and Policy. Oxford: Basil Blackwell; 1987.

[4] Petras, J, Veltmeyer, H. Cardoso's Brazil: A Land for Sale. Boulder CO: Rowman \& Littlefield; 2003.

[5] ECLAC. Statistical Yearbook for Latin America and the Caribbean. Santiago: United Nations; 2012.

[6] Sena-Fobomade. Se intensifica el extractivismo minero en América Latina. Foro Boliviano sobre Medio Ambiente y Desarrollo, 02 marzo; 2011. Available from: http://fobomade.org.bo/art-1109

[7] Kotze, C. South American Mining Sector to Continue as Resource-Based Economy. Mining Weekly [Internet]. La Paz, Bolivia: Foro Boliviano sobre Medio Ambiente y Desarrollo. 2012 June 15. [cited 2016 May 13]. Available from: http://www.miningweekly.com/article/south-american-miningsector-to-continue-as-resource-based-economy-2012-06-15 
[8] UNCTAD - United Nations Conference on Trade and Development. World Investment Report. Non-Equity Modes of International Production and Development. Geneva: United Nations; 2011.

[9] Arellano, JM. Canadian Foreign Direct Investment in Latin America. Background Paper. North-South Institute, Ottawa, May; 2010. Available from: http://s3.amazonaws.com/zanran storage/www.nsi-ins.ca/ContentPages/67816597.pdf.

[10] ECLAC - Economic Commission for Latin America and the Caribbean (2015). Foreign Direct Investment in Latin America. Santiago

[11] Porzecanski, A. Latin America: The Missing Financial Crisis. ECLAC Studies and Perspectives, No. 6. Washington DC: ECLAC; 2009.

[12] Cypher, J. South America's Commodities Boom. Developmental Opportunity or Path Dependent Reversion? Canadian Journal of Development Studies. 2010; 30(3-4):635-662.

[13] ECLAC - Economic Commission for Latin America and the Caribbean. Statistical Yearbook for Latin America and the Caribbean. Santiago: ECLAC; 2004.

[14] Campodónico, H. Renta petrolera y minera en países seleccionados de América Latina. Santiago: CEPAL; 2008.

[15] UNCTAD - United Nations Conference on Trade and Development (2007). World Investment Report 2007: Transnational Corporations, Extractive Industries and Development. Geneva: United Nations; 2007.

[16] CEPAL - Comisión Económico de América Latina y el Caribe (2010). Panorama de la inserción internacional de América Latina y el Caribe 2009-2010. Santiago: UN/CEPAL; 2010 .

[17] Zibechi, R. La nueva geopolítica del capital. ALAI, América Latina en Movimiento / Le Monde Diplomatique Colombia. 2012 April 19. Available from: http://www.alainet.org/es/activ e/54196

[18] UNCTAD - United Nations Conference on Trade and Development. Investment Trend Monitor No. 8. New York: United Nations. 2012 January 24.

[19] FAO - Food and Agricultural Organization of the United Nations. Land Tenure and International Investments in Agriculture. Rome: FAO; 2011.

[20] World Bank. Rising Global Interest in Farmland: Can It Yield Sustainable and Equitable Benefits? Washington, DC: World Bank; 2010.

[21] Borras Jr, S, Franco, J, Gomez, S, Kay, C, Spoor, M. Land Grabbing in Latin America and the Caribbean. Journal of Peasant Studies. 2012; 39(3-4):845-872.

[22] Higginbottom, A. The Political Economy of Foreign Investment in Latin America Dependency Revisited. Latin American Perspectives. 2013 May; 40(3):184-206.

[23] Bello, W. Dilemmas of Domination: The Unmaking of the American Empire. New York: Metropolitan Books; 2005.

[24] Delgado Wise, R, Veltmeyer, H. Agrarian Change, Migration and Development. Halifax: Fernwood Publication; 2015.
[25] Blas, J. Commodity Traders reap \$250bn harvest. Financial Times. 2013 April $14 . \quad$ Available from: http://www.ft.com/intl/cms/s/0/9f6f541e-a397-11e2-ac00-001 44 feabdc $0 . h t m l$

[26] Gudynas, E. Diez tesis urgentes sobre el nuevo extractivismo. Contextos y demandas bajo el progresismo sudamericano actual. In Extractivismo, Política y Sociedad. Quito: CLAES / CAAP; 2009. p 187-225. Available from: http://extractivismo.com/doc umentos/capitulos/GudynasExtractivismoSociedadDesarrollo0 9.pdf

[27] UNDESA-United Nations Department of Economic and Social Affairs. The Inequality Predicament: Report on the World Social Situation. New York: United Nations; 2005.

[28] Veltmeyer, H, Tetreault. D, editors. Poverty and Development in Latin America: Public Policies and Development Pathways. Kumarian Press; 2013.

[29] UNDP - United Nations Development Programme. Regional Human Development Report for Latin America and the Caribbean 2010. New York: UNDP; 2010.

[30] Solón, P. Vivir Bien: Notes for the Debate. Systemic Alternatives; 2014. Available from: https://systemicalternative s.files.wordpress.com/2014/07/buen-vivir-english-30-jul-2014. pdf

[31] Acosta, A. La maldición de la abundancia. Quito: Comité Ecuménico de Proyectos CEP / Ediciones Abya-Yala; 2009.

[32] Auty, RM. Sustaining Development in Mineral Economies: The Resource Curse Thesis. London: Routledge; 1993.

[33] BBC News. Brazil economy grew 0.9\% in 2012. 2013 March 1. Available from: http://www.bbc.co.uk/news/business-21630 930

[34] Konold, M. Commodity Supercycle Slows Down in 2012. Worldwatch Institute. 2013 October 10. Available from: http://www.worldwatch.org/commodity-supercycle-slows-dow n-2012-0

[35] Piketty, T. Capital in the Twenty-First Century. Cambridge: Belknap Press of Harvard University Press; 2014.

[36] Kay, C. Latin American Theories of Development and Underdevelopment. London: Routledge; 1989.

[37] Solanas, F. El despojo de los metales argentinos (Parte IV). Rebelión. 2007 July 31: 1-9. Available from: http://www.rebelion.org/seccion.php?id=9

[38] Cypher, J. Neoextracciónismo y Primarización: ¿la subida y decadencia de los términos del intercambio en América del Sur? Presentation at the International Seminar 'Como Sembrar el Desarrollo en América Latina'. UNAM-Instituto de Investigaciones Económicas. México, DF. 2012 October 29-31.

[39] Foster, JB. Marx's Ecology: Materialism and Nature. New York: Monthly Review; 2000.

[40] Farah, I, Vasapollo, L, coordinators. Vivir bien. ¿Paradigma no-capitalista? La Paz: CIDES-UMSA; 2011. Available from: http://tinyurl.com/z3f2alu

[41] CIDSE/ALAI. América Latina: Riqueza privada, pobreza pública. Quito: CIDSE/Alianza de organizaciones católicas para el desarrollo \& ALAI/Agencia Latinoamericana de Información; 2009. Available from: https://mundoroto.files.wo 
rdpress.com/2016/03/amc3a9rica-latina-riqueza-privada-pobre za-pc3bablica.pdf

[42] Chaparro, E. Industrias extractivas y desarrollo sostenible en América Latina. Santiago: CEPAL; 2006

[43] Escobar, A. Latin America at the crossroads. Cultural Studies. 2010. 24(1): 1-65.

[44] Svampa, M, Antonelli, M. Minería Transnacional, Narrativas del Desarrollo y Resistencias Sociales. Buenos Aires: Editorial Biblos; 2009.

[45] Bebbington, A. The New Extraction: Rewriting the Political Ecology of the Andes? NACLA Report on the Americas. 2009. 42(5): 12-21.

[46] Martinez-Alier, J. The Environmentalism of the Poor: A Study of Ecological Conflicts and Valuation. London: Edward Elgar Publishing; 2003.

[47] Rodriguez, P, Carruthers, D. Testing Democracy's Promise: Indigenous Mobilization and the Chilean State. European Review of Latin American and Caribbean Studies. 2008 October. 87: 3-21. Available from: http://www.erlacs.org/articl es/abstract/10.18352/erlacs.9616/

[48] Tetreault, D. Mexico: The Political Ecology of Mining. In Veltmeyer, H, Petras, J, editors. The New Extractivism. London: Zed Books; 2014. p.172-191.

[49] Ceceña, A, Aguilar, P, Motto, C. Territorialidad de la dominación. Integración de la Infraestructura Regional Sudamericana (IIRSA). Buenos Aires: Observatorio
Latinoamericano de Geopolítica; 2007.

[50] Saguier, M. Minería para el desarrollo integral en la estrategia de UASUR. Presentation to the Conference ISA/FLACSO. Buenos Aires. 2014 July 23-2.

[51] Collier, P, Venables, AJ. Plundered Nations? Successes and Failures in Natural Resource Extraction. London: Palgrave Macmillan; 2011.

[52] Veltmeyer, H, Petras, J. The New Extractivism. London: Zed Books; 2014

[53] Girvan, N. Extractive Imperialism in Historical Perspective. In Petras, J, Veltmeyer, H, editors. Extractive Imperialism in the Americas. Leiden: Brill Books; 2014. p. 49-61.

[54] Harvey, D. The new imperialism. Oxford: Oxford University Press; 2003.

[55] OCMAL-Observatorio de Conflictos Mineros de América Latina. Mapa de conflictos mineros, proyectos y empresas mineras en América Latina. [cited 2011 January 28]. Available from: http://mapa.conflictosmineros.net/ocmal_db/

[56] IWGIA - International Work Group for Indigenous Affairs. The Indigenous World 2010. Copenhagen. 2010. Available from:

http://www.iwgia.org/iwgia files publications files/0001 I 2010_EB.pdf

[57] Foro de los Pueblos indígenas, minería, cambio climático y buen vivir. Suscribe Declaración. Lima: Servicios en Comunicación Intercultural Servindi. 2010 Nov 23. 